\title{
GMR
}

\section{Phenotypic characteristics for discrimination between advanced genotypes of Brachiaria ruziziensis}

\author{
B.A. Rezende ${ }^{1}$, C.B. Ribeiro ${ }^{1}$, D.H.L. Teixeira ${ }^{1}$, F.M.A. Gonçalves ${ }^{1}$ and \\ F. Souza Sobrinho² \\ 'Departamento de Biologia, Universidade Federal de Lavras, Lavras, MG, Brasil \\ ${ }^{2}$ Embrapa Gado de Leite, Juiz de Fora, MG, Brasil \\ Corresponding author: F. Souza Sobrinho \\ E-mail: fausto.souza@embrapa.br
}

Genet. Mol. Res. 15 (1): gmr.15017774

Received October 5, 2015

Accepted December 7, 2015

Published March 31, 2016

DOI http://dx.doi.org/10.4238/gmr.15017774

ABSTRACT. The aim of this study was to use multivariate methods and Pearson and partial correlations to disregard phenotypic characteristics that contribute little to differentiation between Brachiaria ruziziensis genotypes. Eighty-one genotypes of $B$. ruziziensis were assessed in completely randomized blocks with three replications. Ten phenotypic characteristics were assessed: plant height, leaf length, leaf width, sheath length, length of the flower stem, length of the inflorescence axis, number of racemes per inflorescence, length of the basal raceme, number of spikelets per basal raceme, and width of the rachis. The best traits for differentiation between genotypes were determined by assessing relative contribution to diversity, canonical variables, as well as Pearson and partial correlations. Four canonical variables were found to account for $57 \%$ of the overall variation, while plant height, sheath length, and number of racemes per inflorescence were considered traits that could potentially be disregarded in future assessments.

Key words: Plant breeding; Genetic divergence; Correlations between traits; Multivariate analysis 


\section{INTRODUCTION}

The need for distinguishing morphological and agronomic traits to better identify promising genotypes arises in all stages of any crop-breeding program. In highly bred crops, the tendency is for differences among advanced genotypes to be particularly small, which hinders differentiation among them. This is also the case for grasses like Brachiaria ruziziensis.

In Brazil, the assessment of characteristics like plant height, leaf length, length of the inflorescence axis, and number of racemes, among others, is required in grasses only for purposes of registration of cultivars in the Ministério da Agricultura, Pecuária e Abastecimento (MAPA; Ministry of Agriculture, Livestock and Food). Measurement of some of the traits required by MAPA, however, is also common in stages prior to release of the cultivar and demands time, resources, and labor. Especially in the initial and intermediate stages of breeding, such distinguishing traits could be used to identify variability among genotypes and thus to allow a new selection cycle to be generated, thereby maintaining variation for the future. These traits could also be used to identify similar genotypes and thus to establish an improved population to be assessed and tested for possible recommendation.

In this respect, simultaneous assessment of various traits (multivariate analysis) allows different inferences to be made about the entire set of traits used, which, in turn, allows inferences to be made about their usefulness (Ferreira, 2011). A highly useful multivariate method is one in which the relative contribution of traits to diversity is assessed, as proposed by Singh (1981). Based on the Mahalanobis generalized distance $\left(D^{2}\right)$, this technique allows the relative importance of each trait to the total diversity observed in the population under study to be determined. The greater the variability found for a trait, therefore, the greater its importance in relation to the others.

The multivariate technique of canonical variables is highly useful for plant breeding and is adopted especially when the researcher wishes to reduce the number of traits to be assessed to differentiate the genotypes (Cruz et al., 2012). Using this statistical procedure, a set of traits can be reduced to another, smaller set; the importance of each trait to the total variation of the population studied can be assessed; and traits can be eliminated that contribute little to variation (Ferreira, 2011). To complement multivariate methods, the identification of correlated traits aids in disposing of unnecessary traits by indicating redundancy in traits used to assess genotypes. Correlation analysis in conjunction with multivariate analysis is therefore highly useful in forage crop-breeding programs. Thus far, few studies correlating the main traits usually measured in Brachiaria ruziziensis (Assis et al., 2003; Borges et al., 2011) have been reported.

In studies involving a large number of traits, simple Pearson correlation between two traits may be influenced by variation shared with a third trait or a set of traits (Cruz et al., 2012). This effect is not observed with the use of partial correlation, since partial correlation is estimated by eliminating the effects of other traits on the association between the pair of traits involved. That way, a more precise and more informative estimate is obtained with regard to the correlation between the traits under study (Cruz et al., 2012).

The aim of this study was to use multivariate methods and Pearson and partial correlation analyses to discard traits that contribute little to differentiation between B. ruziziensis genotypes.

\section{MATERIAL AND METHODS}

The experimental work for this study was set up in September 2008 in the experimental field of Embrapa Gado de Leite, located in the municipality of Coronel Pacheco, in the Zona da 
Mata region of Minas Gerais ( $21^{\circ} 35^{\prime} 16^{\prime \prime S}, 43^{\circ} 15^{\prime} 56^{\prime \prime W}$, altitude of $\left.484 \mathrm{~m}\right)$. Eighty-one genotypes of B. ruziziensis originating from a population obtained from a recurrent selection cycle used for the identification of genotypes giving rise to higher forage yield and quality were included in the study, and a completely randomized block design with three replications per genotype was used, with plots of " $2 \mathrm{~m}^{2}$ " and four plants per plot.

In the main flowering season (March to May 2009), the plants in the plots were assessed in terms of the following morphological traits: plant height $(\mathrm{PHe}, \mathrm{cm})$, leaf length $(\mathrm{LL}, \mathrm{cm})$, leaf width $(\mathrm{LW}, \mathrm{cm})$, sheath length (SL, cm), length of the flower stem (LFS, cm), length of the inflorescence axis (LIA, cm), number of racemes per inflorescence (NRI), length of basal raceme (LBR, cm), number of spikelets per basal raceme (NSBR), and width of the rachis (WR, cm). Measurements were taken in the plot area.

The resulting data were first subjected to univariate analysis of variance to evaluate divergence among the genotypes. The significance of the effects on the genotypes was assessed for each characteristic using the F-Snedecor test $(P<0.05)$. Traits for which the genotypes exhibited significant variation were included in subsequent multivariate approaches.

The relative contributions of traits to diversity were determined using the method proposed by Singh (1981). The canonical variables were obtained according to the method described by Cruz et al. (2012) and their levels of significance were determined by the F-Snedecor test $(P<$ 0.05). The most highly weighted traits (greatest eigenvectors) among the non-significant canonical variables were eliminated after they were identified from simple Pearson correlations and partial correlations as described by Cruz et al. (2012).

Analyses of variance and the canonical variables were carried out using SAS software (SAS Institute, 2011), specifically using the PROC GLM and PROC CANDISC functions, respectively. Pearson phenotypic correlations, partial correlations, and the relative contributions of traits to diversity were determined using the GENES statistical computation program (Cruz, 2013).

\section{RESULTS}

Analysis of variance of all the traits measured in this study exhibited significant differences among the different genotypes, which indicates genotypic variability among the traits. That is a necessary condition for the other methods already described. Boxplots of the phenotypes of each trait are shown in Figure 1.

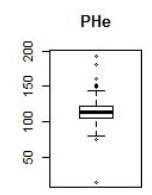

LIA

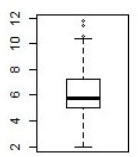

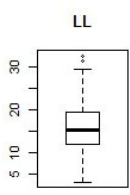

NRI

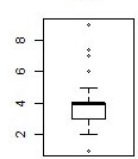

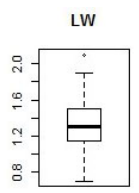

LBR

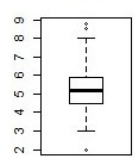

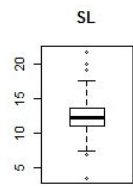

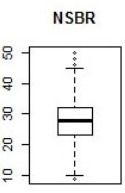

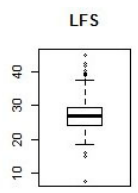

WR

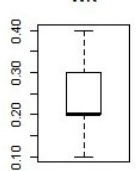

Figure 1. Boxplots of the phenotypes of 81 genotypes of Brachiaria ruziziensis, assessed based on 10 morphological traits: plant height $(\mathrm{PHe})$, leaf length (LL), leaf width (LW), sheath length (SL), length of the flower stem (LFS), length of the inflorescence axis (LIA), number of racemes per inflorescence (NRI), length of basal raceme (LBR), number of spikelets per basal raceme (NSBR), and width of rachis (WR). 
Based on the criteria proposed by Singh (1981), the traits with the greatest relative contribution to genetic divergence were LFS, LBR, LIA, and LL (Figure 2). Together, these traits contribute to approximately $50 \%$ of the divergence across the genotypes assessed. There was a great discrepancy in terms of the relative contributions of the traits involving the raceme: the LBR trait contributed $13.07 \%$, while the NRI contributed only $6.72 \%$. There is therefore less genotypic diversity due to NRI differences than due to LBR differences. The same was shown to be true for the LL and LW leaf traits: LL had a greater effect on diversity than LW.

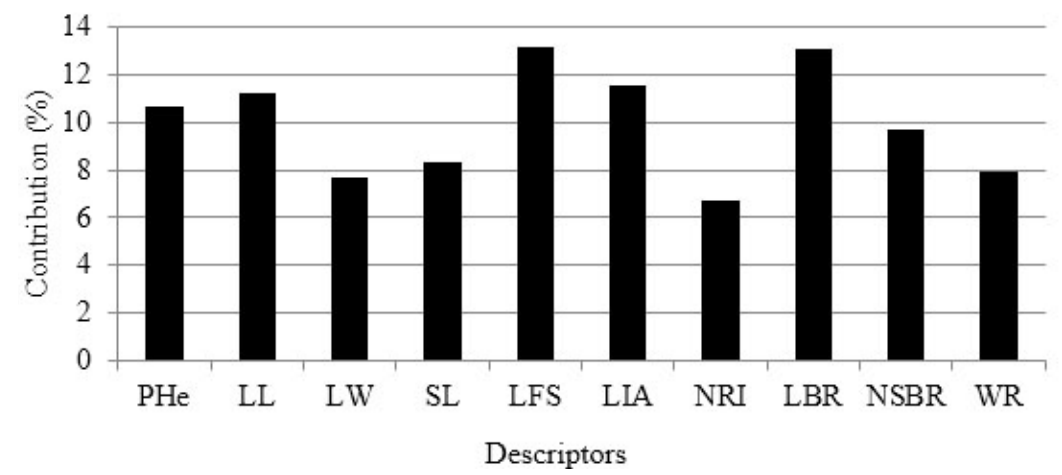

Figure 2. Contributions of plant height (PHe), leaf length (LL), leaf width (LW), sheath length (SL), length of the flower stem (LFS), length of the inflorescence axis (LIA), number of racemes per inflorescence (NRI), length of basal raceme (LBR), number of spikelets per basal raceme (NSBR), and width of rachis (WR) to the genetic diversity.

The canonical variable multivariate method makes use of standardized linear combinations of the original variables (traits) to form a set of variables of the same dimension (canonical variables) that contain, in order of estimation, the maximum variance generated by the original data (Negreiros et al., 2008; Cruz et al., 2012). The last canonical variables estimated thus provide the least information and the original traits of greater weighting (greater eigenvector) among these variables are identified and can therefore be discarded (Cruz et al., 2012).

Among the 10 canonical variables, it was observed that the four of greatest importance for diversity accounted for $57 \%$ of the variation overall (Table 1). The first accounted for $17 \%$ of the variation and all others accounted for less than $15 \%$ of the total variation. Nevertheless, statistical significance was observed up to the eighth canonical variable ( $F$-test).

The data indicate that the great majority of the measured traits were important in differentiating between genotypes, i.e., that the majority of the traits contributed significantly to divergence (Table 1). The traits that contributed least to the divergence by the canonical variables were SL and PHe. These two traits exhibited the greatest eigenvectors among the non-significant canonical variables (variables 9 and 10 ).

Pearson and partial correlation analyses were used to identify redundancy among the traits and thus to eliminate such redundant traits. Estimates of Pearson correlation were found to range from 0 (between WR and LFS) to 0.73 (NRI and LIA) as shown in Table 2. In the vast majority of cases, the estimates for WR were close to zero and non-significant, making it improbable that this trait would be redundant in relation to another. With the second greatest relative contribution to diversity, LBR also exhibited significant correlation with almost all the traits, except for LIA. In contrast, WR, which showed a small relative contribution (7.92\%), was one of the traits that correlated least with the others, as mentioned above. 
Table 1. Variances, percentage variances, and accumulated variances of the canonical variables obtained from 10 traits assessed in 81 clones of Brachiaria ruziziensis.

\begin{tabular}{l|c|c|c|c|c|c}
\hline Variables & Variances & Difference & Proportion (\%) & Accumulated (\%) & $\mathrm{Pr}>\mathrm{F}$ & Discarded variable \\
\hline 1 & 2.16 & 0.3 & 0.17 & 0.17 & ${ }^{* *}$ & - \\
\hline 2 & 1.87 & 0.18 & 0.15 & 0.32 & ${ }^{* *}$ & - \\
\hline 3 & 1.68 & 0.15 & 0.13 & 0.45 & ${ }^{* *}$ & - \\
\hline 4 & 1.54 & 0.35 & 0.12 & 0.57 & ${ }^{* *}$ & - \\
\hline 5 & 1.18 & 0.08 & 0.09 & 0.66 & ${ }^{* *}$ & - \\
\hline 6 & 1.1 & 0.08 & 0.09 & 0.75 & ${ }^{* *}$ & - \\
\hline 7 & 1.02 & 0.11 & 0.08 & 0.83 & ${ }^{* *}$ & - \\
\hline 8 & 0.91 & 0.13 & 0.07 & 0.9 & ${ }^{* *}$ & - \\
\hline 9 & 0.78 & 0.3 & 0.06 & 0.96 & $\mathrm{NS}$ & $\mathrm{PHe}$ \\
\hline 10 & 0.48 & 0 & 0.04 & 1 & $\mathrm{NS}$ & $\mathrm{SL}$ \\
\hline
\end{tabular}

**and NS: significant and non-significant, respectively, by the $F$-test at $95 \%$ reliability.

Table 2. Correlations between morphological traits, where Pearson correlation coefficients are shown above the diagonal and partial correlation coefficients below the diagonal.

\begin{tabular}{|c|c|c|c|c|c|c|c|c|c|c|}
\hline & $\mathrm{PHe}^{1}$ & $\mathrm{LL}^{1}$ & $\mathrm{LW}^{1}$ & $S L^{1}$ & LFS $^{1}$ & $\mathrm{LIA}^{1}$ & $\mathrm{NRI}^{1}$ & $\mathrm{LBR}^{1}$ & $\mathrm{NSBR}^{1}$ & $W^{1}$ \\
\hline $\mathrm{PHe}$ & - & 0.05 & 0.2 & $0.43^{* *}$ & $0.34^{* *}$ & $0.36^{\star *}$ & $0.25^{*}$ & $0.30^{*}$ & 0.2 & 0.05 \\
\hline LL & -0.15 & - & $0.48^{\star *}$ & 0.01 & $0.42^{* *}$ & -0.1 & -0.22 & $0.34^{\star \star}$ & $0.31^{* \star}$ & 0.17 \\
\hline LW & 0.23 & $0.42^{* *}$ & - & -0.22 & $0.31^{* *}$ & 0.17 & 0.04 & $0.25^{*}$ & 0.16 & -0.02 \\
\hline $\mathrm{SL}$ & $0.34^{*}$ & 0.04 & $-0.43^{\star *}$ & - & 0.21 & $0.26^{*}$ & 0.16 & $0.28^{*}$ & $0.34^{\star *}$ & $0.26^{*}$ \\
\hline LFS & 0.22 & 0.3 & 0.08 & 0.11 & - & 0.12 & -0.12 & $0.39^{* *}$ & $0.29^{* \star}$ & 0 \\
\hline LIA & -0.04 & -0.15 & 0.15 & 0.14 & 0.14 & - & $0.73^{\star *}$ & 0.1 & 0.03 & -0.05 \\
\hline NRI & 0.19 & 0.02 & 0.02 & 0.03 & -0.17 & $0.77^{\star *}$ & - & $-0.31^{\star \star}$ & -0.12 & -0.05 \\
\hline LBR & 0.2 & 0.08 & 0.08 & 0.05 & 0.07 & $0.44^{* *}$ & $-0.55^{\star \star}$ & - & $0.45^{* \star}$ & $0.28^{*}$ \\
\hline NSBR & -0.05 & 0.14 & 0.08 & 0.3 & 0.03 & -0.11 & 0.06 & 0.3 & - & 0.07 \\
\hline WR & -0.07 & 0.16 & -0.01 & 0.25 & -0.14 & -0.18 & 0.16 & 0.3 & -0.16 & - \\
\hline
\end{tabular}

${ }_{*, * \star}$ Significant at 95 and $99 \%$ reliability, respectively, as determined by the $t$-test (Steel et al., 1997).

Since the estimated correlation between two traits may be due in part to the association of a third or more additional traits, partial correlations should be chosen whenever possible. As the partial correlation parameter is determined by eliminating the effect of other variables on the association between the traits involved, it provides more precise estimates of true correlations between traits (Cruz et al., 2012).

Table 2 shows that many of the correlation estimates found to be significant with Pearson correlation became non-significant with partial correlation. The opposite was also observed (Table 2). For the LFS, NSBR, and WR traits the partial correlation estimates were non-significant, i.e., these traits are not redundant with any others. For all the trait pairs in which there was a change in significance, there are likely to be other associated traits that affect the Pearson correlation.

The results shown in Figure 2, Table 1, and Table 2 allow us to make inferences regarding the possibility of discarding some traits. From the canonical variable results (Table 1), the traits with greatest weighting for the non-significant variables were PHe and SL, which makes it plausible to discard them. The SL trait also showed the fourth lowest contribution to diversity by the Singh (1981) 
method (Figure 2), which reinforces the case for discarding it. The Singh method also identifies NRI as a trait that may be discarded, since NRI exhibited the smallest contribution among all the traits.

\section{DISCUSSION}

The traits found to have the smallest contributions were NRI, LW, WR, and SL (in order from the lowest contribution). The lower contributions of these traits are an indication of the small variability found for these traits in comparison to the others in B. ruziziensis. In spite of these findings, it should be noted that discarding traits based only on these criteria is not advisable since, even if a trait shows a low level of relative contribution, it may still be important for genetic divergence (Marim et al., 2009; Azevedo et al., 2013).

According to the canonical method used in this study, only the two traits PHe and SL were redundant or contributed little to genotype differentiation and may therefore be eliminated. According to Pereira et al. (1992), the distribution of variance of the canonical variables is associated with the number of traits used in the analysis, such that the first canonical variables contribute to the greatest variances only when a reduced number of traits are used.

In breeding programs, the number of traits assessed is often increased to yield more information on the genetic diversity among genotypes. Daher et al. (1997), however, point out that increasing the number of traits does not always improve differentiation between genotypes because, if a trait contributes to the detection of variability already differentiated by another trait, there is redundancy between them, and the second can be discarded. Removal of redundant traits is therefore advantageous in that it reduces the amount of data collection required and improves data interpretation (Pereira et al., 1992).

The divergent results observed between different methods of correlation analysis for some pairs of traits show that, when assessing a large group of traits, correlations must be interpreted with care. Nevertheless, the correlation between NRI and LIA determined by Pearson correlation analysis (0.73) changed little when assessed by partial correlation analysis (0.77). One of the traits in this pair could be discarded since the two correlation analyses demonstrated redundancy between the two traits.

The Pearson phenotypic correlations and partial correlations indicated that NRI and LIA are highly correlated (Table 2), which demonstrates redundancy and therefore that one of the traits could be discarded. Since NRI was shown to contribute less to diversity than LIA and correlated highly with LIA, NRI could be eliminated as an assessment trait in future analyses.

Multivariate methods have already been used in identifying traits that are best for discrimination between genotypes in various crops (Fonseca and da Silva, 1999; Ribeiro et al., 1999; Martel et al., 2003; Coelho et al., 2007; Oliveira et al., 2007; Silva et al., 2008; Pinto et al., 2010; Cabral et al., 2011); however, the use of such methods for B. ruziziensis has not been reported. For the genus Brachiaria, Assis et al. (2003) assessed vegetative, reproductive and pubescence traits (24 traits in all) for the purpose of correct placement of 301 accessions in the species to which they belonged. For that purpose, they established discriminating functions by the multivariate method of Anderson (1958). The authors concluded that the vegetative and reproductive traits were the most efficient in discriminating between the six species of Brachiaria assessed, deeming the pubescence traits ineffective in such differentiation.

In the present study, the statistical analyses carried out indicated that the PHe, SL, and NRI traits could be disregarded as traits useful in differentiating between different genotypes for the purposes of registering $B$. ruziziensis cultivars in MAPA. In addition to the statistical results 
presented, it is worth noting that $\mathrm{PHe}$ and $\mathrm{SL}$ in particular are difficult traits to measure, and precision in their measurement is highly dependent on the training of the researcher responsible for this task. Since it is not always possible to count on duly trained labor, we consider the discarding of these traits, together with NRI, which was found to contribute little to divergence, appropriate for $B$. ruziziensis genetic breeding programs.

\section{Conflicts of interest}

The authors declare no conflict of interest.

\section{ACKNOWLEDGMENTS}

Research supported by Embrapa Gado de Leite and Coodernação de Aperfeiçoamento Pessoal de Nível Superior (CAPES).

\section{REFERENCES}

Anderson TW (1958). An introduction to multivariate statistical analysis. John Wiley \& Sons, New York, 374.

Assis GML, Euclydes RF, Cruz CD and do Valle CB (2003). Discriminação de espécies de Brachiaria baseada em diferentes grupos de caracteres morfológicos. RBZ 32: 576-584.

Azevedo AM, Andrade Júnior VC, Oliveira CM, Fernandes JSC, et al. (2013). Seleção de genótipos de alface para cultivo protegido: divergência genética e importância de caracteres. Hortic. Bras. 31: 260-265. http://dx.doi.org/10.1590/S0102$\underline{05362013000200014}$

Borges V, Sobrinho FS, Ledo FJ da S and Kopp MM (2011). Associação entre caracteres e análise de trilha na seleção de progênies de meios-irmãos de Brachiaria ruziziensis. Rev. Ceres 58: 765-772. http://dx.doi.org/10.1590/S0034737X2011000600013

Cabral PDS, Soares TCBS, Lima ABP, Alves DS, et al. (2011). Diversidade genética de acessos de feijão comum por caracteres agronômicos. Rev. Cienc. Agron. 42: 898-905. http://dx.doi.org/10.1590/S1806-66902011000400011

Coelho CMM, Coimbra JLM, de Souza CA, Bogo A, et al. (2007). Diversidade genética em acessos de feijão (Phaseolus vulgaris L.). Cienc. Rural 37: 1241-1247. http://dx.doi.org/10.1590/S0103-84782007000500004

Cruz CD (2013). GENES - a software package for analysis in experimental statistics and quantitative genetics. Acta Scientiarum 35: 271-276.

Cruz CD, Regazzi AJ and Carneiro PCS (2012). Modelos Biométricos Aplicados ao Melhoramento Genético. 4th edn. Viçosa: Editora UFV. 2: 514.

Daher RF, Moraes CF and Cruz CD (1997). Seleção de caracteres morfológicos em capim-elefante (Pennistum purpureum Schum.). Rev. Bras. Zootec. 26: 247-259.

Ferreira DF (2011). Estatística Multivariada. 2nd edn. Lavras: Editora UFLA, 676.

Fonseca JR and da Silva HT (1999). Identificação de acessos de feijão por meio de técnicas multivariadas. Pesquisa Agropecu. Bras. 34: 409-414. http://dx.doi.org/10.1590/S0100-204X1999000300012

Marim BG, Silva DJH, Carneiro PCS, Miranda GV, et al. (2009). Variabilidade genética e importância relativa de caracteres em acessos de germoplasma de tomateiro. Pesquisa Agropecu. Bras. 44: 1283-1290. http://dx.doi.org/10.1590/S0100204X2009001000011

Martel JHI, Ferraudo AS, Moroô JR and Perecin D (2003). Estatística multivariada na discriminação de raças amazônicas de Pupunheira (Bactris gasipaes Kunth) em Manaus (Brasil). Rev. Bras. Frutic. 25: 115-118. http://dx.doi.org/10.1590/ $\underline{\text { S0100-29452003000100033 }}$

Negreiros JS, Alexandre RS, Álvares VS, Bruckner CH, et al. (2008). Divergência genética entre progênies de maracujazeiroamarelo com base em características da plântula. Rev. Bras. Frutic. 30: 197-201. http://dx.doi.org/10.1590/S0100$\underline{29452008000100036}$

Oliveira M do SP de, Ferreira DF and Santos JB dos (2007). Divergência genética entre acessos de açaizeiro fundamentada em descritores morfoagronômicos. Pesq. Agropecu. Bras. 42: 501-506. http://dx.doi.org/10.1590/S0100204X2007000400007

Pereira AV, Vencovsky R and Cruz CD (1992). Selection of botanical and agronomical descriptors for the characterization of cassava (Manihot esculenta Crantz.) germplasm. Rev. Bras. Genet. 15: 115-124. 
Pinto JFN, Reis EF, Faleiro FG, Barbosa ECC, et al. (2010). Seleção de descritores vegetativos para caracterização de acessos de guariroba (Syagrus oleracea (Mart.) Becc. Rev. Bras. Frutic. 32: 832-839. http://dx.doi.org/10.1590/S0100$\underline{29452010005000094}$

Ribeiro FE, Soares AR and Ramalho MAP (1999). Divergência genética entre populações de coqueiro-gigante-do-Brasil. Pesquisa Agropecu. Bras. 34: 1615-1622. http://dx.doi.org/10.1590/S0100-204X1999000900012

SAS Institute Inc. (2011). Base SAS $\otimes^{9} 9.3$ Procedures Guide. Cary, NC: SAS Institute Inc.

Silva GO, Pereira AS, Souza VQ, Carvalho FIF, et al. (2008). Importância de caracteres na dissimilaridade de progênies de batata em gerações iniciais de seleção. Bragantia 67: 141-144. http://dx.doi.org/10.1590/S0006-87052008000100017

Singh D (1981). The relative importance of characters affecting genetic divergence. Indian J. Genet. Plant Breed. 41: 237-245

Steel RGD, Torrie JH and Dickey DA (1997). Principles and procedures of statistics: a biometrical approach. 3rd edn. McGrawHill, New York. 